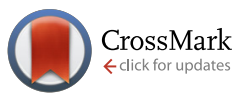

Cite this: Med. Chem. Commun., $2015,6,1673$

Received 26th March 2015, Accepted 29th July 2015

\section{DOI: $10.1039 / \mathrm{c} 5 \mathrm{md} 00119 f$}

www.rsc.org/medchemcomm

\title{
Synthesis of carboxyimidamide-substituted benzo[c][1,2,5]oxadiazoles and their analogs, and evaluation of biological activity against Leishmania donovani $\uparrow$
}

\author{
Leena Keurulainen, ${ }^{a}$ Mikko Heiskari, ${ }^{a}$ Satu Nenonen, ${ }^{a}$ Abedelmajeed Nasereddin, ${ }^{b}$ \\ Dmitry Kopelyanskiy, ${ }^{b}$ Teppo O. Leino, ${ }^{a}$ Jari Yli-Kauhaluoma, ${ }^{a}$ Charles L. Jaffe ${ }^{b}$ and \\ Paula Kiuru*a
}

\begin{abstract}
A facile synthesis route to carboxyimidamide-substituted benzoxadiazoles and related derivatives was developed. A total of 25 derivatives were synthesized. They were evaluated for antileishmanial activity by inhibition of Leishmania donovani axenic amastigote growth using a fluorescent viability microplate assay. The most promising derivative (14) demonstrated an antileishmanial EC 50 of $4.0 \mu \mathrm{M}$, and it also showed activity in infected macrophages ( $\mathrm{EC}_{50} 5.92 \mu \mathrm{M}$ ) without signs of cytotoxicity.
\end{abstract}

\section{Introduction}

Leishmaniasis is a spectrum of human diseases caused by at least 20 different species of protozoan parasites. These parasites are responsible for three major diseases: cutaneous, visceral, and mucocutaneous. Over 300 million people are at risk. ${ }^{1}$ Visceral leishmaniasis (VL), caused primarily by $L$. donovani (anthroponotic) or L. infantum/L. chagasi (zoonotic), is fatal if left untreated. There are an estimated 300000 cases of VL per year, and 20000 to 40000 deaths. Over $90 \%$ of new cases occur in six countries: Bangladesh, Brazil, Ethiopia, India, South Sudan, and Sudan. Although two new drugs, miltefosine and paromomycin, are currently in use and combination therapy is becoming more common, ${ }^{2}$ an urgent need for new antileishmanial chemotypes persists. The major issues to be confronted in Leishmania treatment are the toxicity of primary medicines and the development of parasite resistance.

In addition, poor efficacy in the case of visceral leishmaniasis/HIV coinfection has raised the need for new antileishmanial treatments. ${ }^{3}$

In our previous study, 2-arylbenzimidazole and benzo [c]$[1,2,5]$ oxadiazole derivatives showed activity against the intracellular Gram-negative bacterium Chlamydia pneumoniae. ${ }^{4}$ In that study, a similarity-based model of $C$. pneumoniae dimethyladenosine transferase was used to virtually screen

\footnotetext{
${ }^{a}$ Faculty of Pharmacy, Division of Pharmaceutical Chemistry and Technology, University of Helsinki, Viikinkaari 5 E, P. O. Box 56, FI-00014 Helsinki, Finland. E-mail: paula.kiuru@helsinki.fi

${ }^{b}$ Department of Microbiology and Molecular Genetics, IMRIC, Hebrew UniversityHadassah Medical School, P. O. Box 12272, Jerusalem 9112102, Israel

$\dagger$ Electronic supplementary information (ESI) available: Synthesis procedures for compounds 6-13, 15-18, 21-39. See DOI: 10.1039/c5md00119f
}

compounds from commercially available databases against $C$. pneumoniae. The 2-arylbenzimidazoles found were then tested and proven active against $L$. donovani. ${ }^{5}$ This prompted us to consider benzo $[c][1,2,5]$ oxadiazole-derived compounds as a new family of antileishmanial agents. In addition, benzoxadiazoles and their $N$-oxides have been previously studied as antibiotic and antiparasitic agents. ${ }^{6}$ In this study, a facile synthesis route to carboxyimidamide-substituted benzoxadiazoles was developed, a set of 25 benzo $[c][1,2,5]$ oxadiazole derivatives and other structurally related compounds was synthesized and evaluated as antileishmanial agents.

\section{Results and discussion}

\subsection{Chemistry}

Initially, benzo $[c][1,2,5]$ oxadiazole-5-carbonitrile 4 was to be synthesized from 5-chloro- or 5-bromobenzo[c][1,2,5]oxadiazole in a microwave-assisted reaction using $\mathrm{NaCN}$, $\mathrm{CuCN}$, or $\mathrm{K}_{4}\left[\mathrm{Fe}(\mathrm{CN})_{6}\right],{ }^{7}$ but these syntheses failed to produce the target nitrile. Instead the synthesis of benzo[c][1,2,5]oxadiazole derivatives was started from the commercially available 4-amino-3-nitrobenzoic acid (Scheme 1). It was converted to benzo[c] $][1,2,5]$ oxadiazole-5-carboxylic acid (1) by using a two-step procedure via the $\mathrm{N}$-oxide intermediate that was produced in the presence of sodium hypochlorite in an alkaline EtOH- $\mathrm{H}_{2} \mathrm{O}$ solution and subsequently reduced to the carboxylic acid $1 .^{8}$ Next, compound 1 was converted to the primary amide 3 via the acyl chloride 2 in the presence of aqueous ammonia in 1,4-dioxane. The reaction of the obtained primary amide 3 with trifluoroacetic anhydride and $\mathrm{Et}_{3} \mathrm{~N}$ in $\mathrm{THF}^{9}$ gave the corresponding nitrile 4, which was converted to the amidoxime 5 by using hydroxylamine 
<smiles></smiles><smiles>O=C(Cl)c1ccc2nonc2c1</smiles><smiles>O=C(NOC(=O)c1ccc2nonc2c1)Nc1ccccc1</smiles><smiles>N#Cc1ccc2nonc2c1-c1cc(C(N)=O)cc2nonc12</smiles><smiles>O=C(O)c1ccc2nonc2c1</smiles><smiles>[R]C1=C=CC=C(NC(=O)O/N=C(\N)c2ccc3nonc3c2)C=C1</smiles>

$6 \mathrm{R}=\mathrm{H}, 7 \mathrm{R}=2-\mathrm{Me}, 8 \mathrm{R}=3-\mathrm{Me}, 9 \mathrm{R}=4-\mathrm{Me}, 10 \mathrm{R}=2-\mathrm{OMe}$, $11 \mathrm{R}=3-\mathrm{OMe}, 12 \mathrm{R}=4-\mathrm{OMe}, 13 \mathrm{R}=2-\mathrm{Cl}, 14 \mathrm{R}=3-\mathrm{Cl}$, $15 \mathrm{R}=4-\mathrm{Cl}, 16 \mathrm{R}=2-\mathrm{CF}_{3}, 17 \mathrm{R}=3-\mathrm{CF}_{3}, 18 \mathrm{R}=4-\mathrm{CF}_{3}$

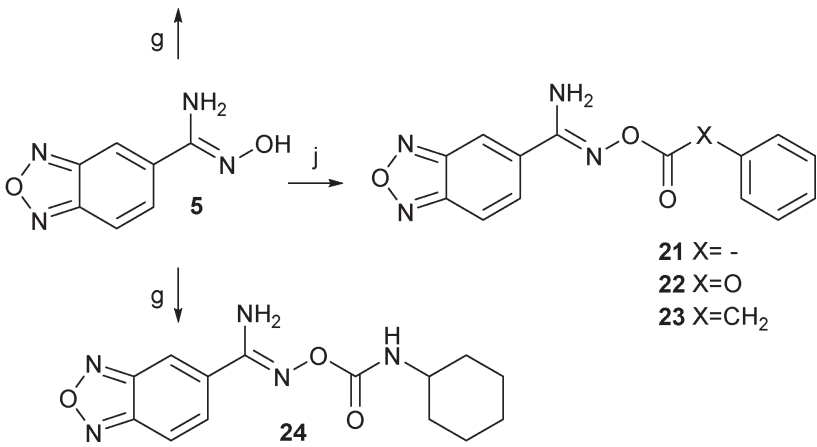

Scheme 1 Synthetic procedures and chemical structures of the products 2-24. Reagents and conditions: a) $\mathrm{KOH}, \mathrm{EtOH}, \mathrm{H}_{2} \mathrm{O}, 70{ }^{\circ} \mathrm{C}, 2 \mathrm{~h}$, then $\mathrm{NaOCl}, 0^{\circ} \mathrm{C} \rightarrow \mathrm{rt}, 21 \mathrm{~h}, 87 \%$; b) $\mathrm{P}(\mathrm{OEt})_{3}, \mathrm{EtOH}, 70{ }^{\circ} \mathrm{C}, 17 \mathrm{~h}, 67 \%$; c) $\mathrm{SOCl}_{2}$, reflux, $4 \mathrm{~h}, 97 \%$; d) $\mathrm{NH}_{3}$ aq., 1,4-dioxane, $0{ }^{\circ} \mathrm{C}, 1.5 \mathrm{~h}, 90 \%$; e) TFAA, Et $3 \mathrm{~N}$, $\mathrm{THF}, \mathrm{rt}, 3 \mathrm{~h}, 79 \%$; f) $\mathrm{H}_{2} \mathrm{NOH} \cdot \mathrm{HCl}, \mathrm{Et}_{3} \mathrm{~N}, \mathrm{EtOH}, \mathrm{rt}, 2 \mathrm{~h}, 94 \%$; g) substituted phenyl isocyanate, THF or $\mathrm{CHCl}_{3}, \mathrm{rt}, 3-21$ or $96-120$ h, 27-70\%; h) $\mathrm{MeOH}$, $0{ }^{\circ} \mathrm{C}, 0.5 \mathrm{~h}$ then $\mathrm{H}_{2} \mathrm{NOH} \cdot \mathrm{HCl}, \mathrm{MeOH}, \mathrm{rt}, 1.5 \mathrm{~h}, 57 \%$; i) $\mathrm{THF}$, phenyl isocyanate, $57 \%$; j) $\mathrm{PhCOCl} / \mathrm{PhOCOCl} \mathrm{PhCH}_{2} \mathrm{COCl}, \mathrm{Et}_{3} \mathrm{~N}, \mathrm{THF}, 70{ }^{\circ} \mathrm{C}, 2-4 \mathrm{~h}$, $14-63 \%$.

hydrochloride ${ }^{10}$ in the presence of $\mathrm{Et}_{3} \mathrm{~N}$ in $\mathrm{EtOH}$. The final step to obtain the derivatives $(\mathbf{6}-\mathbf{1 8}, \mathbf{2 4})$ was carried out in the presence of the substituted phenyl isocyanates in THF or $\mathrm{CHCl}_{3}$. The products 21-23 were synthesized in a similar manner by using a solution of $\mathrm{Et}_{3} \mathrm{~N}$ in THF. Compound 20 was synthesized from the acyl chloride 2 via the hydroxamic acid 19. The final products 33-39 were synthesized from the commercially available nitriles by using the methods described above (Scheme 2). Finally, the related benzimidazole derivative 25 was formed from 3,4-diaminobenzonitrile in refluxing formic acid. ${ }^{11}$

\subsection{Evaluation of antileishmanial activity}

The activity of the new compounds was determined by using a fluorescent viability microplate assay with $L$. donovani

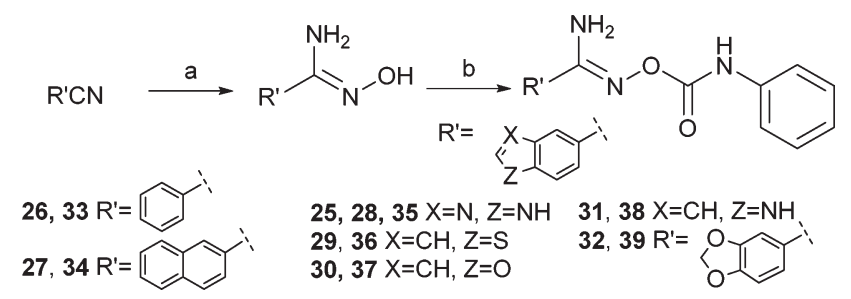

Scheme 2 Synthetic procedures and chemical structures of the products 25-39. Reagents and conditions: a) $\mathrm{H}_{2} \mathrm{NOH} \cdot \mathrm{HCl}, \mathrm{Et}_{3} \mathrm{~N}$ or $\mathrm{Na}_{2} \mathrm{CO}_{3}, \mathrm{EtOH}$ or $\mathrm{H}_{2} \mathrm{O}, \mathrm{rt} / 100{ }^{\circ} \mathrm{C}, 3.5-24 \mathrm{~h}, 38-98 \%$; b), phenyl isocyanate, $\mathrm{THF}, \mathrm{CHCl}_{3}$ or $1,4-$ dioxane, $\mathrm{rt}, 2-5 \mathrm{~h}$ or $72 \mathrm{~h}, 6-85 \%$. axenic amastigotes and alamarBlue. ${ }^{12}$ All compounds were initially screened at $50 \mu \mathrm{M}$, and the most active derivatives sequentially tested at lower concentrations (15 and $5 \mu \mathrm{M})$.

First, a set of benzo[c][1,2,5] oxadiazole derivatives 6-18, with different substitution patterns in the "Eastern" phenyl ring of the structure, were synthesized and assayed. The derivative with no additional substituents (compound 6) showed $70 \%$ and $24 \%$ inhibition of $L$. donovani proliferation at $50 \mu \mathrm{M}$ and $15 \mu \mathrm{M}$, respectively, whereas meta-Cl substitution (compound 14) increased growth inhibition to $95 \%$ and $87 \%$ at $50 \mu \mathrm{M}$ and $15 \mu \mathrm{M}$, respectively (Table 1). Overall, meta substitution including Cl-, OMe-, $\mathrm{Me}-$, and $\mathrm{CF}_{3}$-substituted derivatives seems to be beneficial for antileishmanial activity.

Replacing $\mathrm{HN}$ of the heteroatom containing chain with oxygen or carbon atom (compounds 22 and 23) significantly reduced antileishmanial activity to 27 and $22 \%$, respectively, at $50 \mu \mathrm{M}$. Similarly, removal of the aniline $\mathrm{NH}$ (compound 21) reduced activity, but this compound still showed more activity (51\% growth inhibition) than carboxy 22 or benzylic 23 derivatives. Moreover, the cyclohexane derivative 24 displays leishmanial inhibition in the absence of an aniline moiety. Replacement of the amino group in the imidamide 20 with a carbonyl group increased inhibition to $96 \%$ and $68 \%$ at concentrations of $50 \mu \mathrm{M}$ and $15 \mu \mathrm{M}$, respectively.

Finally, a second set of related heterocyclic compounds was synthesized with replacements of the benzo[c] $[1,2,5]$ oxadiazole moiety. These heterocycles (benzothiophene 36, benzofuran 37, indole 38, and 1,3-benzodioxole 39) showed 
Table 1 Inhibition of Leishmania donovani axenic amastigote growth

\begin{tabular}{|c|c|c|c|}
\hline \multirow[b]{2}{*}{ Compound } & \multicolumn{3}{|c|}{$\%$ inhibition $^{a}$} \\
\hline & $50 \mu \mathbf{M}$ & $15 \mu \mathrm{M}$ & $5 \mu \mathrm{M}$ \\
\hline 6 & 70.1 & 24.2 & - \\
\hline 7 & 42.0 & - & - \\
\hline 8 & 67.2 & 44.6 & - \\
\hline 9 & 64.1 & - & - \\
\hline 10 & $38.0^{b}$ & - & - \\
\hline 11 & 71.4 & 31.8 & - \\
\hline 12 & 46.0 & - & - \\
\hline 13 & $29.6^{b}$ & - & - \\
\hline 14 & 94.8 & 87.2 & 43.4 \\
\hline 15 & 44.0 & - & - \\
\hline 16 & 42.1 & - & - \\
\hline 17 & 51.4 & - & - \\
\hline 18 & 51.7 & - & - \\
\hline 20 & 96.2 & 68.2 & 54.6 \\
\hline 21 & 51.1 & - & - \\
\hline 22 & 26.5 & - & - \\
\hline 23 & 22.4 & - & - \\
\hline 24 & $43.9^{b}$ & - & - \\
\hline 33 & 78.4 & 5.4 & - \\
\hline 34 & 98.8 & 24.9 & - \\
\hline 35 & 72.0 & - & - \\
\hline 36 & 97.9 & 35.2 & - \\
\hline 37 & 95.2 & 48.0 & - \\
\hline 38 & 91.9 & 21.6 & - \\
\hline 39 & 93.0 & 33.9 & - \\
\hline Amphotericin B & - & - & $99.7^{c}$ \\
\hline
\end{tabular}

an increase in antileishmanial activity at $50 \mu \mathrm{M}$ compared to the benzoxazole derivative 6 . This suggests that the benzo[c]$[1,2,5]$ oxadiazole ring is not crucial to antileishmanial activity. In addition, the phenyl and naphthalene derivatives 33 and 34 significantly inhibited growth of $L$. donovani amastigotes (78\% and $5 \%$ for 33 , and $99 \%$ and $25 \%$ for 34 , at concentrations of $50 \mu \mathrm{M}$ and $15 \mu \mathrm{M}$, respectively). Good inhibition of compound 34 can be hypothesized to result from increased lipophilicity of the compound. Moreover, the phenyl derivative 33 is a very interesting compound, because the shorter synthetic route is likely to increase the prospects for further preparation of new antileishmanial derivatives of this chemotype.

Further evaluation of the most promising derivatives 14 and 20 revealed low $\mathrm{EC}_{50}$ values on axenic amastigotes, 4.2 and $8.1 \mu \mathrm{M}$ respectively; moderate cytotoxicity on the human THP-1 macrophage cell line, 79.9 and $33.7 \mu \mathrm{M}$ respectively; and no cytotoxicity against murine fibroblasts at the highest concentration tested, $300 \mu \mathrm{M}$ (Table 2). Values for amphotericin B, a reference compound used to treat leishmaniasis, are given for comparison. When tested at $5 \mu \mathrm{M}$ on infected macrophages, a concentration non-toxic for the macrophage cell line, both compounds, 14 and 20, were still active, 33.1 and $19.9 \%$ amastigote growth inhibition respectively, albeit lower than that observed with axenic amastigotes. The $\mathrm{EC}_{50}$ for 14, the most active and least cytotoxic derivative, on intracellular amastigotes in infected macrophages was $5.92 \mu \mathrm{M}$ similar to that observed using axenic amastigotes.

\section{Conclusion}

The developed synthesis route to carboxyimidamidesubstituted benzo[c] $[1,2,5]$ oxadiazoles and related derivatives facilitates access to a compound library and determination of the structure-activity relationships for this antileishmanial heterocyclic chemotype. Carboxyimidamide-substituted benzoxadiazole derivative $\mathbf{1 4}$ is the most promising compound of this study, demonstrating good antileishmanial inhibition activity in infected macrophages and, remarkably, no signs of cytotoxicity. Although mechanism of action of the compounds is not known yet, it is worth continuing the development of these compounds to explore further prospects of these compounds.

\section{Experimental section}

\subsection{Chemistry}

Unless otherwise stated, reactions were carried out in ovendried glassware under an argon atmosphere. All reagents were commercially available and were acquired from Fluka (Buchs, Switzerland), Aldrich (Schnelldorf, Germany), Riedelde Haën (Seelze, Germany), and Alfa Aesar (Karlsruhe, Germany). THF was distilled over sodium/benzophenone ketyl. The progress of chemical reactions was monitored by thinlayer chromatography on silica gel $60-\mathrm{F}_{254}$ plates acquired from E. Merck (Darmstadt, Germany). The eluent consisted of EtOAc and $n$-hexane, or EtOAc and $\mathrm{MeOH}$, and detection was conducted at 254 or $366 \mathrm{~nm}$. The products were purified by flash chromatography on silica gel with a Biotage SP1 purification system (Uppsala, Sweden) using $25+\mathrm{M}$ cartridges or SNAP $10 \mathrm{~g}, 25 \mathrm{~g}$, or $50 \mathrm{~g}$ cartridges, detection at $254 \mathrm{~nm}$. Melting points were measured using an IA9100 digital melting point apparatus (Electrothermal Engineering, Essex, UK) and

Table $2 \mathrm{EC}_{50}$ of the selected derivatives on Leishmania donovani axenic amastigotes and intracellular amastigotes in L. donovani-infected macrophages; cytotoxicity on THP-1 macrophages and NIH/3T3 fibroblasts; and respective selectivity indices [SI]

\begin{tabular}{lllll}
\hline & Axenic amastigotes & Intracellular amastigotes & $\begin{array}{l}\text { THP-1 EC } \mathrm{EC}_{50}(\mu \mathrm{M}) \\
(n=2)[\mathrm{SI}]\end{array}$ & $\begin{array}{l}\text { Fibroblasts EC } \\
(n=2)[\mathrm{SI}]\end{array}$ \\
\hline $\mathbf{E C}(\mu \mathrm{M})$ & $79.9 \pm 5.4[19.0]$ & $>300[>71.4]$ \\
$\mathbf{1 4}$ & $4.2 \pm 0.2$ & $5.92 \pm 1.7$ & $33.7 \pm 5.0[4.2]$ & $>300[>37.0]$ \\
Amphotericin B & $8.1 \pm 0.9$ & - & $2.1-7.6$ (ref. 15 and 16) & 2.2 (ref. 18)
\end{tabular}


are uncorrected. IR spectra were recorded on a Bruker Vertex 70 FT-IR spectrometer (Ettlingen, Germany) with ATR technique. The synthesized compounds were analyzed by NMR on a Varian Mercury $300 \mathrm{MHz}$ spectrometer (Palo Alto, CA, USA). ${ }^{1} \mathrm{H}$ and ${ }^{13} \mathrm{C}$ NMR were recorded as solutions in DMSO- $d_{6}$ (Aldrich). Chemical shifts $(\delta)$ are given in parts per million (ppm) relative to the NMR solvent signals (DMSO- $d_{6} 2.50$ and $39.51 \mathrm{ppm}$ for ${ }^{1} \mathrm{H}$ and ${ }^{13} \mathrm{C} \mathrm{NMR}$, respectively). LC-MS analyses were performed with a HP1100 instrument (Agilent, Palo Alto, USA) with UV detector ( $\lambda 210 \mathrm{~nm}$ ) and an Esquire LC spectrometer (Bruker Daltonik, Bremen, Germany) with ESI ion source. Signal separation was carried out by the use of a Waters XBridge C18 column $(2.1 \mathrm{~mm} \times 50 \mathrm{~mm}, 2.1 \mu \mathrm{m})$ with a Waters XBridge C18 guard column (Milford, MA, USA) (2.1 $\mathrm{mm} \times 10 \mathrm{~mm}, 2.5 \mu \mathrm{m})$. The eluent consisted of water $(+0.1 \%$ $\left.\mathrm{HCO}_{2} \mathrm{H}\right)$ and acetonitrile $\left(+0.1 \% \mathrm{HCO}_{2} \mathrm{H}\right.$ ) (gradient run $80: 20$ $\rightarrow 5$ :95). Purity of all tested compounds was $>95 \%$. High resolution mass spectra (HRMS) were measured on a Synapt G2 HDMS Q-TOF-instrument (Milford, MA, USA) with positive mode ESI.

Benzo[ $[c][1,2,5]$ oxadiazole-5-carboxylic acid (1). Potassium hydroxide (2.02 g, $36.0 \mathrm{mmol}, 2.4$ equiv.) was dissolved in equimixture of EtOH and $\mathrm{H}_{2} \mathrm{O}(40 \mathrm{~mL})$. 4-Amino-3-nitrobenzoic acid $(2.73 \mathrm{~g}, 15.0 \mathrm{mmol})$ was added to this solution, and the resulting mixture was heated at $70{ }^{\circ} \mathrm{C}$ for $2 \mathrm{~h}$ and cooled to $0{ }^{\circ} \mathrm{C}$. A $13 \%$ aqueous solution of sodium hypochlorite $(80 \mathrm{~mL})$ was added dropwise to this solution during 30 min. The resulting mixture was slowly allowed to warm to $\mathrm{rt}$ and stirred for $21 \mathrm{~h} . \mathrm{H}_{2} \mathrm{O}(35 \mathrm{~mL})$ was added at $0{ }^{\circ} \mathrm{C}$, and the mixture was acidified $(\mathrm{pH}<1)$ with a $6 \mathrm{M}$ aqueous solution of $\mathrm{HCl}$ resulting in the formation of a yellow precipitate. Sodium chloride (1.9 g) was added, and the mixture was further stirred for $1.5 \mathrm{~h}$, filtered, and dried in vacuo to yield benzo $[c][1,2,5]$ oxadiazole-5-carboxylic acid 1-oxide (2.4 g, 87\%) as a yellow solid. ${ }^{1} \mathrm{H}$ NMR (300 MHz, DMSO- $\left.d_{6}\right) \delta 8.06$ (br s, 1H), 7.84 (br s, 1H), 7.73 (br s, 1H). A mixture of benzo[c][1,2,5] oxadiazole-5-carboxylic acid 1-oxide (1.90 g, $10.5 \mathrm{mmol})$ in absolute EtOH $(25 \mathrm{~mL})$ was heated to $70{ }^{\circ} \mathrm{C}$, and triethyl phosphite (2.80 mL, $16.0 \mathrm{mmol}, 1.5$ equiv.) was added dropwise to the mixture. The resulting mixture was heated to reflux and the reflux was maintained for $17 \mathrm{~h}$. The solvent was evaporated, and the residual black oil was treated with $\mathrm{H}_{2} \mathrm{O}$ and extracted twice with EtOAc. The organic phase was extracted with a $2 \mathrm{M}$ aqueous solution of $\mathrm{NaOH}$, and the aqueous phase was washed three times with EtOAc. The aqueous phase was cooled to $0{ }^{\circ} \mathrm{C}$ and acidifed $(\mathrm{pH}<1)$ with a $6 \mathrm{M}$ aqueous solution of $\mathrm{HCl}$ resulting in the formation of a light brown precipitate, which was filtered and dried in vacuo to yield the compound $1(1.10 \mathrm{~g}, 67 \%)$ as a brown solid. ${ }^{1} \mathrm{H}$ NMR (300 MHz, DMSO- $\left.d_{6}\right) \delta 13.7$ (br s, $\left.1 \mathrm{H}\right), 8.63$ (t, $J=1.1 \mathrm{~Hz}, 1 \mathrm{H}), 8.13(\mathrm{dd}, J=9.4,1.1 \mathrm{~Hz}, 1 \mathrm{H}), 7.97$ (dd, $J=9.4$, $1.1 \mathrm{~Hz}, 1 \mathrm{H}) .{ }^{13} \mathrm{C}$ NMR (75 Hz, DMSO- $\left.d_{6}\right) \delta 165.6,149.3,148.9$, 134.7, 131.4, 119.4, 116.6. ${ }^{1} \mathrm{H}$ spectral data is consistent with those reported earlier. ${ }^{14}$

Benzo $[c][1,2,5]$ oxadiazole-5-carbonyl chloride (2). A mixture of benzo $[c][1,2,5]$ oxadiazole-5-carboxylic acid 1 (1.82 g, 11.1 mmol) and thionyl chloride (18 $\mathrm{mL}$ ) was refluxed for $4 \mathrm{~h}$. The resulting mixture was concentrated and dried in vacuo to yield $2(2.0 \mathrm{~g}, 97 \%)$ as a brown solid. ${ }^{1} \mathrm{H}$ NMR (300 MHz, DMSO- $\left.d_{6}\right)$ $\delta 8.62(\mathrm{t}, J=1.1 \mathrm{~Hz}, 1 \mathrm{H}), 8.12(\mathrm{dd}, J=9.4,1.1 \mathrm{~Hz}, 1 \mathrm{H}), 7.96$ (dd, $J=9.4,1.1 \mathrm{~Hz}, 1 \mathrm{H}) .{ }^{13} \mathrm{C}$ NMR $\left(75 \mathrm{~Hz}, \mathrm{DMSO}-d_{6}\right) \delta 165.4$, 149.3, 148.9, 134.6, 131.3, 119.4, 116.6.

Benzo $[c][1,2,5]$ oxadiazole-5-carboxamide (3). A $25 \%$ aqueous solution of ammonia $(4.8 \mathrm{~mL})$ was cooled in an ice bath. To this solution, compound $2(0.700 \mathrm{~g}, 3.80 \mathrm{mmol})$ in 1,4-dioxane $(8 \mathrm{~mL})$ was added dropwise. The resulting mixture was stirred at the same temperature for $1.5 \mathrm{~h}$ and then evaporated in vacuo. The residue was dissolved in EtOAc and washed with $\mathrm{H}_{2} \mathrm{O}$. The aqueous phase was extracted twice with EtOAc. The combined organic phases were dried over anhydrous $\mathrm{Na}_{2} \mathrm{SO}_{4}$, evaporated, and dried in vacuo to yield 3 $(0.56 \mathrm{~g}, 90 \%)$ as a light orange solid. ${ }^{1} \mathrm{H}$ NMR $(300 \mathrm{MHz}$, DMSO- $\left.d_{6}\right) \delta 8.55$ (t, $\left.J=1.2 \mathrm{~Hz}, 1 \mathrm{H}\right), 8.32$ (br s, 1H), 8.12 (dd, $J$ = 9.4, $1.2 \mathrm{~Hz}, 1 \mathrm{H}), 7.97(\mathrm{dd}, J=9.4,1.2 \mathrm{~Hz}, 1 \mathrm{H}), 7.79(\mathrm{br} \mathrm{s}$, 1H). ${ }^{13} \mathrm{C}$ NMR (75 MHz, DMSO- $\left.d_{6}\right) \delta 166.0,149.1,148.9$, 137.8, 131.4, 116.2, 115.8 .

Benzo $[c][1,2,5]$ oxadiazole-5-carbonitrile (4). Compound 3 $(1.50 \mathrm{~g}, 9.20 \mathrm{mmol})$ was dissolved in anhydrous THF $(30 \mathrm{~mL})$, and distilled $\mathrm{Et}_{3} \mathrm{~N}$ (2.80 mL, $20.2 \mathrm{mmol}, 2.2$ equiv.) was added to this solution. The solution was cooled in an ice bath, and trifluoroacetic anhydride $(1.50 \mathrm{~mL}, 11.0 \mathrm{mmol}, 1.2$ equiv.) in THF ( $8 \mathrm{~mL})$ was added dropwise. The resulting mixture was stirred at $\mathrm{rt}$ for $3 \mathrm{~h} . \mathrm{H}_{2} \mathrm{O}$ was added and the volatiles were removed in vacuo. The residue was dissolved in $\mathrm{CH}_{2} \mathrm{Cl}_{2}$ and washed twice successively with a $0.1 \mathrm{M}$ aqueous solution of $\mathrm{HCl}$ and a $0.1 \mathrm{M}$ aqueous solution of $\mathrm{NaOH}$. The organic phase was dried over anhydrous $\mathrm{Na}_{2} \mathrm{SO}_{4}$, evaporated, and dried in vacuo. The crude product was purified by flash column chromatography (EtOAc/n-hexane $1: 2)$ to give $4(1.10$ $\mathrm{g}, 79 \%)$ as a pink solid. ${ }^{1} \mathrm{H}$ NMR $\left(300 \mathrm{MHz}\right.$, DMSO- $\left.d_{6}\right) \delta 8.98$ (t, $J=1.2 \mathrm{~Hz}, 1 \mathrm{H}), 8.28(\mathrm{dd}, J=9.3,1.2 \mathrm{~Hz}, 1 \mathrm{H}), 7.82(\mathrm{dd}, J=$ 9.3, $1.2 \mathrm{~Hz}, 1 \mathrm{H}) .{ }^{13} \mathrm{C}$ NMR (75 MHz, DMSO- $\left.d_{6}\right) \delta 148.4,147.9$, 131.8, 125.7, 118.3, 117.2, 115.4 .

$N^{\prime}$-Hydroxybenzo $[c][1,2,5]$ oxadiazole-5-carboximidamide (5). A mixture of compound 4 (1.05 g, $7.20 \mathrm{mmol})$, $\mathrm{H}_{2} \mathrm{NOH} \cdot \mathrm{HCl}$ (750 mg, $10.8 \mathrm{mmol}, 1.5$ equiv.) and distilled $\mathrm{Et}_{3} \mathrm{~N}(1.50 \mathrm{~mL}, 10.8 \mathrm{mmol})$ in $\mathrm{EtOH}(45 \mathrm{~mL})$ was stirred at $\mathrm{rt}$ for $2 \mathrm{~h}$. The solvent was evaporated and the residue was dissolved in EtOAc and brine. The organic phase was washed with brine, dried over anhydrous $\mathrm{Na}_{2} \mathrm{SO}_{4}$, evaporated, and dried in vacuo to yield $5(1.2 \mathrm{~g}, 94 \%)$ as a yellowish solid. ${ }^{1} \mathrm{H}$ NMR (300 MHz, DMSO- $\left.d_{6}\right) \delta 10.38(\mathrm{~s}, 1 \mathrm{H}), 8.29(\mathrm{t}, J=1.1 \mathrm{~Hz}$, $1 \mathrm{H}), 8.03(\mathrm{dd}, J=9.6,1.1 \mathrm{~Hz}, 1 \mathrm{H}), 7.96(\mathrm{dd}, J=9.6,1.1 \mathrm{~Hz}$, 1H), $6.13(\mathrm{~s}, 2 \mathrm{H}) .{ }^{13} \mathrm{C}$ NMR (75 MHz, DMSO- $\left.d_{6}\right) \delta$ 149.2, 149.0, 148.7, 136.4, 130.9, 115.2, 110.7.

$N^{\prime}$-[[(3-Chlorophenyl)carbamoyl $]$ oxy $]$ benzo[c][1,2,5]oxadiazole-5-carboximidamide (14). A mixture of $5(89.0 \mathrm{mg}$, $0.500 \mathrm{mmol})$, and isocyanate ( $0.550 \mathrm{mmol}, 1.1$ equiv.) in dry THF ( $5 \mathrm{~mL}$ ) was stirred at rt for $4 \mathrm{~h}$. The solvent was evaporated. The crude product was purified by flash $\mathrm{SiO}_{2}$ column chromatography (EtOAc/n-hexane 1:2) to give $14(0.10 \mathrm{~g}$, $60 \%)$ as a white powder. ${ }^{1} \mathrm{H}$ NMR $\left(300 \mathrm{MHz}, \mathrm{DMSO}-d_{6}\right) \delta 9.68$ 
(s, 1H), $8.57(\mathrm{~s}, 1 \mathrm{H}), 8.14-8.13(\mathrm{~m}, 2 \mathrm{H}), 7.73-7.71(\mathrm{~m}, 1 \mathrm{H})$, 7.52 (dd, $J=8.4,1.2 \mathrm{~Hz}), 7.36$ (t, $J=8.4 \mathrm{~Hz}, 1 \mathrm{H}), 7.18(\mathrm{~s}, 2 \mathrm{H})$, $7,12$ (dd, $J=8.4,1.2 \mathrm{~Hz}, 1 \mathrm{H}) .{ }^{13} \mathrm{C}$ NMR (75 MHz, DMSO- $\left.d_{6}\right) \delta$ 153.6, 152.1, 148.9, 148.8, 140.0, 134.9, 133.1, 131.4, 130.4, 122.8, 118.8, 117.8, 116.0, 114.6. LC-MS: $[\mathrm{M}+\mathrm{H}]^{+} 332.0 \mathrm{~m} / \mathrm{z}$ $\left(t_{\mathrm{r}}=6.9 \mathrm{~min}\right)$. FT-IR (ATR, $\left.\mathrm{cm}^{-1}\right): 3440,3349,1739,1647$, 1274. HRMS (ESI): $m / z$ calcd. for $\mathrm{C}_{14} \mathrm{H}_{10} \mathrm{ClN}_{5} \mathrm{O}_{3}[\mathrm{M}+\mathrm{H}]^{+}$ 332.0550, found 332.0551.

$N$-Hydroxybenzo $[c][1,2,5]$ oxadiazole-5-carboxamide Compound 2 (183 mg, $1.00 \mathrm{mmol}$ ) was stirred in $\mathrm{MeOH}$ (5 $\mathrm{mL}$ ) in an ice bath for $30 \mathrm{~min}$. The solvents were evaporated in vacuo to give methyl benzo[c] $[1,2,5]$ oxadiazole-5-carboxylate. A solution of hydroxylamine in $\mathrm{MeOH}$ was prepared by dissolving $\mathrm{H}_{2} \mathrm{NOH} \cdot \mathrm{HCl}$ (542 $\mathrm{mg}, 7.80 \mathrm{mmol}, 7.8$ equiv.) in $\mathrm{MeOH}$ (5 mL) in a water-ice bath. $\mathrm{KOH}$ (645 mg, $11.5 \mathrm{mmol}$, 11.5 equiv.) in $\mathrm{MeOH}(10 \mathrm{~mL})$ was added, resulting in formation of a precipitate. The resulting mixture was stirred in an ice-water bath for $30 \mathrm{~min}$, and the precipitate was filtered off to yield a solution of $N$-hydroxycarboxamide in $\mathrm{MeOH}$. The methyl ester (vide supra) was dissolved in this solution, stirred for $1.5 \mathrm{~h}$, neutralized with acetic acid, and evaporated. The resulting residue was dissolved in EtOAc and washed with brine. The aqueous phase was further extracted with EtOAc. The combined organic phases were dried over with anhydrous $\mathrm{Na}_{2} \mathrm{SO}_{4}$, evaporated, and dried in vacuo. The crude product was purified by flash $\mathrm{SiO}_{2}$ column chromatography $\left(\mathrm{CH}_{2} \mathrm{Cl}_{2} / \mathrm{MeOH} 9: 1\right)$ to yield $19(0.10 \mathrm{~g}, 57 \%)$ as a light solid. ${ }^{1} \mathrm{H}$ NMR (300 MHz, DMSO- $d_{6}$ ) $\delta 11.56$ (br s, 1H), 9.40 (br s, $1 \mathrm{H}), 8.37$ (s, 1H), 8.14 (dd, $J=9.4,1.0 \mathrm{~Hz}, 1 \mathrm{H}), 7.88$ (dd, $J=$ 9.4, $1.0 \mathrm{~Hz}, 1 \mathrm{H}) .{ }^{13} \mathrm{C}$ NMR (75 MHz, DMSO- $\left.d_{6}\right) \delta$ 161.7, 149.0, 148.7, 139.6, 131.0, 116.5, 114.8 .

$N$-[(Phenylcarbamoyl)oxy]benzo[c] $[1,2,5]$ oxadiazole-5-carboxamide (20). A mixture of $19(128 \mathrm{mg}, 0.70 \mathrm{mmol})$ and phenyl isocyanate ( $87 \mu \mathrm{L}, 0.77 \mathrm{mmol}, 1.1$ equiv.) in dry THF (5 $\mathrm{mL}$ ) was stirred at ice-water bath temperature for $30 \mathrm{~min}$. The resulting mixture was let warm to rt, stirred for $3 \mathrm{~h}$, evaporated, and dried in vacuo. The crude product was purified by flash $\mathrm{SiO}_{2}$ column chromatography $\left(\mathrm{CH}_{2} \mathrm{Cl}_{2} / \mathrm{MeOH} 19: 1\right)$ to yield $20(0.12 \mathrm{~g}, 57 \%)$ as a light brownish solid. ${ }^{1} \mathrm{H}$ NMR (300 MHz, DMSO- $d_{6}$ ) $\delta 12.79$ (br s, 1H), 10.38 (br s, 1H), 8.55 (t, $J$ $=1.2 \mathrm{~Hz}, 1 \mathrm{H}), 8.22(\mathrm{dd}, J=9.5,1.2 \mathrm{~Hz}, 1 \mathrm{H}), 7.92(\mathrm{dd}, J=9.5$, $1.2 \mathrm{~Hz}, 1 \mathrm{H}), 7.52-7.49(\mathrm{~m}, 2 \mathrm{H}), 7.37-7.32(\mathrm{~m}, 2 \mathrm{H}), 7.11-7.05$ $(\mathrm{m}, 1 \mathrm{H}) .{ }^{13} \mathrm{C}$ NMR (75 MHz, DMSO- $\left.d_{6}\right) \delta 163.0,152.0,149.1$, 148.6, 138.0, 134.9, 130.6, 129.0, 123.3, 118.5, 117.1, 116.7. LC-MS: $[\mathbf{M}+\mathbf{H}]^{+} 299.2 \mathrm{~m} / z\left(t_{\mathrm{r}}=5.2 \mathrm{~min}\right)$. FT-IR (ATR, $\left.\mathrm{cm}^{-1}\right)$ : 3321, 3224, 1759, 1663, 1535, 1203, 888. HRMS (ESI): $m / z$ calcd. for $\mathrm{C}_{14} \mathrm{H}_{11} \mathrm{~N}_{4} \mathrm{O}_{4}[\mathrm{M}+\mathrm{H}]^{+}$299.0780, found 299.0779 .

\subsection{Biology}

Antileishmanial evaluation using axenic amastigotes. $L$. donovani (MHOM/SD/1962/1S-Cl2d) was used in all bioassays. Screening of the compounds for antileishmanial activity using axenic amastigotes was carried out using the alamarBlue (AbD Serotec, Oxford, UK) viability assay, as previously described, similar to that reported for leishmanial promastigotes. ${ }^{12}$ Axenic amastigotes were grown at $37^{\circ} \mathrm{C}$ in a $5 \% \mathrm{CO}_{2}$ incubator in complete RPMI 1640 containing $20 \%$ fetal calf serum, $\mathrm{pH}$ 5.5. ${ }^{13}$ Compounds to be assayed were diluted in the complete amastigote medium containing $1 \%$ DMSO to twice the final concentration used in the assays, and were aliquoted in triplicate $(125 \mu \mathrm{L}$ per well) into 96 -well flat-bottom plates (Nunc, Roskilde, Denmark). For determination of the $\mathrm{EC}_{50}$, final concentrations in triplicate spanning 300 to $0.14 \mu \mathrm{M}$ were used. Amastigotes $\left(5.0 \times 10^{5}\right.$ cells per $\mathrm{mL} ; 125 \mu \mathrm{L}$ per well) were added to each well and incubated for $24 \mathrm{~h}$ at $37{ }^{\circ} \mathrm{C}$ in a $5 \% \mathrm{CO}_{2}$ incubator. The alamarBlue viability indicator was added $(25 \mu \mathrm{L}$ per well) and the plates incubated for an additional $24 \mathrm{~h}$ at which time the fluorescence $\left(\lambda_{\mathrm{ex}}=544 \mathrm{~nm} ; \lambda_{\mathrm{em}}=590 \mathrm{~nm}\right)$ was measured in a microplate reader (Fluoroskan Ascent FL, Finland). Complete medium, both with and without DMSO, was used as negative controls ( $0 \%$ inhibition of amastigote growth). Amphotericin B (Sigma-Aldrich, St. Louis MO), a drug used to treat VL, was included as a positive control on each plate and gave $>90 \%$ inhibition of parasite growth at $1.5 \mu \mathrm{M}$.

Cytotoxicity. $\mathrm{EC}_{50}$ was determined on NIH/3T3 fibroblasts or THP-1 monocyte cells using the alamarBlue viability indicator as follows. Cells in DMEM medium plus $10 \%$ fetal calf serum and antibiotics were aliquoted in triplicate (fibroblast or THP-1 at $8 \times 10^{5}$ or $6.4 \times 10^{4}$ cells per well respectively; 125 $\mu \mathrm{L}$ per well) into 96-well plates (Nunc, Roskilde, Denmark). Compounds to be assayed were diluted in the same medium containing 1\% DMSO at twice the final concentration used in the assays (300 to $0.14 \mu \mathrm{M}$ for fibroblasts or 150 to $0.10 \mu \mathrm{M}$ for THP-1), added to the cells $(125 \mu \mathrm{L}$ per well), and the plates incubated for $48 \mathrm{~h}$ at $37{ }^{\circ} \mathrm{C}$ in a $5 \% \mathrm{CO}_{2}$ incubator. The alamarBlue viability indicator was added ( $25 \mu \mathrm{L}$ per well) and the plates incubated for an additional 3-5 $\mathrm{h}$ at which time the fluorescence $\left(\lambda_{\mathrm{ex}}=544 \mathrm{~nm} ; \lambda_{\mathrm{em}}=590 \mathrm{~nm}\right.$ ) was measured. Complete medium, both with and without DMSO, was used as negative controls ( $0 \%$ inhibition).

Activity on intracellular amastigotes. Inhibition of amastigote growth in infected THP-1 cells was measured as previously described. ${ }^{5}$ In brief, THP- 1 cells in complete RPMI-1640 containing $10 \%$ fetal calf serum and antibiotics were treated for $24 \mathrm{~h}$ with $25 \mathrm{ng} \mathrm{mL} \mathrm{m}^{-1}$ phorbol 12-myristate13-acetate (PMA, Sigma-Aldrich, St. Louis, MO). PMA and non-adherent cells were removed with excess warm medium, and stationary-phase $L d$ :pSSU-int/LUC promastigotes expressing luciferase (5:1 parasite/macrophage ratio) used to infect the macrophages. Twenty-four hours later the adherent cells were washed 4-5 times with warm RPMI-1640 alone, and infected macrophages detached by treating with Trypsin EDTA. Infected macrophages $\left(5 \times 10^{4}\right.$ cells $/ 100 \mu \mathrm{L}$ per well $)$ were dispensed in triplicate into white 96-well flat bottom plates (NUNC, Denmark) and the compounds diluted in complete RPMI-1640 containing 1\% DMSO final concentration and added in triplicate (50 $\mu \mathrm{L}$ per well). Cultures were incubated for a further $48 \mathrm{~h}\left(37^{\circ} \mathrm{C}, 5 \% \mathrm{CO}_{2}\right)$, lysed by the addition of Bright-Glo Luciferase Assay substrate $(100 \mu \mathrm{L}$ per well, Promega, MT, U.S.A.), and chemiluminescence measured 
using a microplate reader (Fluoroskan Ascent, Thermo Scientific). Amphotericin B ( $1 \mu \mathrm{M},>90 \%$ inhibition of parasite growth) was included as a positive control. Complete medium, both with and without DMSO, was used as negative controls. Experiments were repeated three times. Calculation of the $\mathrm{EC}_{50}$ 's and statistical analysis were carried out using GraphPad Prism Version 6.0b (GraphPad Software, Inc. San Diego, CA).

\section{Acknowledgements}

We thank Ms. Anna Keltikangas née Takala for the synthesis assistance. This study was supported by the Academy of Finland (projects 264020 and 265481 to JYK). CLJ holds the Michael and Penny Feiwel Professorial Chair of Dermatology.

\section{Notes and references}

1 J. Alvar, I. D. Vélez, C. Bern, M. Herrero, P. Desjeux, J. Cano, J. Jannin, M. den Boer and the WHO Leishmaniasis Control Team, PLoS One, 2012, 7, e35671, Sustaining the drive to overcome the global impact of neglegted tropical diseases, Second WHO Report of Neglegted Diseases, 2013.

2 M. L. den Boer, J. Alvar, R. N. Davidson, K. Ritmeijer and M. Balasegaram, Expert Opin. Emerging Drugs, 2009, 14, 395-410.

3 S. L. Croft, S. Sundar and A. H. Fairlamb, Clin. Microbiol. Rev., 2006, 19, 111-126; J. Alvar, P. Aparicio, A. Aseffa, M. D. Boer, C. Cañavate, J.-P. Dedet, L. Gradoni, R. T. Horst, R. López-Vélez and J. Moreno, Clin. Microbiol. Rev., 2008, 21, 334-359.

4 J. K. O. Alvesalo, A. Siiskonen, M. J. Vainio, P. S. M. Tammela and P. M. Vuorela, J. Med. Chem., 2006, 49, 2353-2356.

5 L. Keurulainen, A. Siiskonen, A. Nasereddin, N. SacerdotiSierra, D. Kopelyanskiy, T. O. Leino, P. Tammela, C. L. Jaffe, J. Yli-Kauhaluoma and P. Kiuru, Bioorg. Med. Chem. Lett., 2015, 25, 1933-1937.

6 S. D. Jorge, A. Masunari, C. O. Rangel-Yagui, K. F. M. Pasqualoto and L. C. Tavares, Bioorg. Med. Chem., 2009, 17, 3028-3036; Y. Cho, T. R. Ioerger and J. C. Sacchettini, J. Med. Chem., 2008, 51, 5984-5992; L. Boiani, C. Davies, C.
Arredondo, W. Porcal, A. Merlino, A. Gerpe, M. Boiani, J. P. Pacheco, M. Á. Basombrío, H. Cerecetto and M. González, Eur. J. Med. Chem., 2008, 43, 2229-2237; D. Castro, L. Boiani, D. Benitez, P. Hernández, A. Merlino, C. Gil, C. Olea-Azar, M. González, H. Cerecetto and W. Porcal, Eur. J. Med. Chem., 2009, 44, 5055-5065.

7 R. K. Arvela and N. E. Leadbeater, J. Org. Chem., 2003, 68, 9122-9125; D. Wang, L. Kuang, Z. Li and K. Ding, Synlett, 2008, 69-72; Y. Ren, W. Wang, S. Zhao, X. Tian, J. Wang, W. Yin and L. Cheng, Tetrahedron Lett., 2009, 50, 4595-4597.

8 R. Mueller and L. J. Street, US Pat., 0122861, 2012.

9 E. A. A. Wallén, J. A. M. Christiaans, M. M. Forsberg, J. I. Venäläinen, P. T. Männistö and J. Gynther, J. Med. Chem., 2002, 45, 4581-4584.

10 H. Käsnänen, M. J. Myllymäki, A. Minkkilä, A. O. Kataja, S. M. Saario, T. Nevalainen, A. M. P. Koskinen and A. Poso, ChemMedChem, 2010, 5, 213-231.

11 M. Muzerelle, A. Quattropani, C. Montage and J. Dorbais, WO Pat., 069949, 2010.

12 O. Shimony and C. L. Jaffe, J. Microbiol. Methods, 2008, 75, 196-200.

13 A. Debrabant, M. B. Joshi, P. F. P. Pimenta and D. M. Dwyer, Int. J. Parasitol., 2004, 34, 205-217.

14 M. Vermeersch, R. Inocencio da Luz, K. Tote, J.-P. Timmermans, P. Cos and L. Maes, Antimicrob. Agents Chemother., 2009, 53, 3855-3859.

15 M. de Rycker, I. Hallyburton, J. Thomas, L. Campbell, S. Wyllie, D. Joshi, S. Cameron, I. H. Gilbert, P. G. Wyatt, J. A. Frearson, A. H. Fairlamb and D. W. Gray, Antimicrob. Agents Chemother., 2013, 57, 2913-2922.

16 S. Oh, B. Kwon, S. Kong, G. Yang, N. Lee, D. Han, J. Goo, J. L. Siqueira-Neto, L. H. Freitas-Junior, M. Liuzzi, J. Lee and R. Song, Med. Chem. Commun., 2014, 5, 142-146.

17 K. Seifert, P. Escobar and S. L. Croft, J. Antimicrob. Chemother., 2010, 65, 508-511.

18 Y. S. Rizk, A. Fischer, M. de Castro Cunha, P. O. Rodrigues, M. C. S. Marques, M. de Fatima, C. Matos, M. C. T. Kadri, C. A. Carollo and C. C. P. de Arruda, Mem. Inst. Oswaldo Cruz, 2014, 109, 1050-1056. 